\title{
Priorities in English Pronunciation Teaching in EFL Classrooms
}

\author{
Moedjito \\ Joint Graduate School, Hyogo University of Teacher Education, Student Dormitory \\ 2-307, Naruto University of Education, \\ 99-7 Nakajima Takashima Naruto-cho Naruto-shi Tokushima, Japan 772-0051 \\ e-mail: moedjito2307@hotmail.com; moedjito2307@gmail.com.
}

\begin{abstract}
This paper reports the priorities in English pronunciation teaching in Indonesian EFL classrooms focusing on the English varieties, components of pronunciation, and techniques for pronunciation teaching. The results indicated that (1) international English was valued as a more appropriate variety for Indonesian learners, (2) and that while depending on a limited range of rather traditional techniques of pronunciation instruction, Indonesian EFL teachers valued segmental features more than suprasegmental features.
\end{abstract}

Key words: international English, pronunciation priorities, techniques for pronunciation teaching

In the two last decades there have been significant changes in the worldwide political, social, and commercial developments. These changes have partially influenced the status and roles of English which consequently need to be re-examined (Jenkins, 2000; McKay, 2002). The fact that English is regarded as the world's principal international language results in the increment of inter-speaker interaction: between native speakers and non-native speakers (NS-NNS) and between non-native speakers (NNS-NNS) (Jenkins, 2000; Walker, 2001).

The pedagogical implication of this situation is that there is a need to revise the goals of teaching English for ESL/EFL learners. In pronunciation teaching, the goal is neither to help learners to attain native-like accents nor to promote comfortable intelligibility to native speakers, but to ensure mutual intelligibility among non-native speakers of English (Jenkins, 2000; McKay, 2002). Therefore, in designing a pronunciation teaching model we should try to identify those phonological and phonetic features that will affect mutual intelligibility for EIL (English as an International Language) 
listeners and subsequently to revise pedagogic measures to facilitate the accurate production of these features by EIL speakers.

In the context of English language education in Indonesia, however, pronunciation has not received enough attention. As a result, there is no systematic clear guideline of pronunciation teaching although English is one of the important compulsory subjects at secondary schools. Many Indonesian teachers of English do not know what aspects of English pronunciation to teach and how to teach them. They are fundamentally not sure which English variety they should introduce to students in their classrooms because several English varieties (e.g., American English, British English, and Australian English) exist throughout Indonesia.

Numerous applied linguists assert that pronunciation teaching basically includes both segmental and suprasegmental features although they have set up the priorities differently. In the case of comfortable intelligibility, for example, pronunciation teaching covers the nature of speech sound (consonants and vowels), stress, rhythm, intonation, and connected speech (Celce-Murcia, Brinton, \& Goodwin, 1996; Dalton \& Seidlhofer, 1994; Cruttenden, 2001; Jenner, 1989). Unlike these researchers, Jenkins (2000) pays more attention to interaction between nonnative speakers of English by formulating Lingua Franca Core (LFC) which is crucial to intelligible pronunciation in EIL context — on the basis of her empirical research. Jenkins argues that the core features of pronunciation should be (1) consonant inventory with the provisos such as some substitutions of $/ \theta /$ and $/ \delta /$ and rhotic ' $r$ '; (2) additional phonetic requirements such as aspiration of word-initial voiceless stops $/ \mathrm{p} /, \mathrm{t} /$, and $\mathrm{k} /$, and shortening of vowel sounds before fortis consonants and maintaining the length before lenis consonants; (3) consonants clusters with consideration of omission and addition; (4) vowel sounds; and (5) production and placement of nuclear stress. Jenkins is also concerned with certain holistic factors involved in the production of sounds because "problems in all these articulatory areas have the potential to lead to pronunciation errors at both segmental and suprasegmental levels, and thus to affect intelligibility" (p. 157).

Like the priorities of pronunciation, how to teach pronunciation is also one of the debatable areas in pronunciation teaching. It is accepted as axiomatic by language teachers that good pronunciation is necessary for the mastery of a new language. However, exactly how they translate this idea into the methodologies and techniques for teaching pronunciation is a 
question which admits much less clarity and consensus. This situation makes teachers and researchers investigate better techniques for teaching pronunciation. Celce-Murcia, M., Brinton, D. M., \& Goodwin, J. M. (1996), for example, recommend numerous techniques for teaching English pronunciation such as (1) listen and imitate, (2) phonetic training, (3) minimal pair drills, (4) contextualised minimal pairs, (5) visual aids, (6) tongue twister, (7) practice of vowels shifts and stress shifts related to affixation, (8) developmental approximation drills, (9) reading aloud/recitation, and (10) recordings of learners' production. These techniques, of course, have their own strengths and weaknesses. A certain technique may be worthwhile in a specific situation but cannot be implemented in other situations. It is unquestionably the teacher is the one who decides which techniques are more appropriate to learners because he/she is the only person who knows what is happening in his/her language classroom.

Apart from what to teach and how to teach, the issue of English variety has recently emerged in the framework of pronunciation teaching. The global development of the world has shifted the roles of English and has subsequently created a new English variety, namely English as an international language (EIL) (Jenkins, 2000; McKay, 2002). In that way, not only is English widely spoken by its native speakers, but also by those whose native language is not English. Such being a case, EIL can exist at any interactions between the speakers of English who come from different nationalities or linguistic backgrounds. As insisted by Jenkins (2000), the main concern should be about non-native speakers of English (NNSs) or non-bilingual English speakers (NBESs) because these speakers are regarded as the "most international" group of English speakers. According to Smith (McKay, 2002), the framework of EIL should be understood in terms of the relationship between an international language and its culture. Smith's assertions are valid for the use of EIL in a global sense (McKay, 2002) on the following conditions: (1) its learners do not need to internalise the cultural norms of native speakers of that language; (2) the ownership of an international language becomes 'de-nationalized'; and (3) the educational goal of learning that language is to enable learners to communicate their ideas and cultures to others.

The development of language teaching on other sides of the globe has a significant influence on English language teaching in Indonesia; as a result, English curricula have been reformed for better outcomes in the last 
three decades. However, many applied linguists and practitioners (e.g., Basir, 2002; Soenjono, 2001; Sudiyana, 2005) still claim that not only are students' achievement and the results of the national examination at secondary schools (junior and senior high schools) unsatisfactory, but also the ability of oral communication is insufficient after completing six-year instruction of English at junior and senior high schools. In the case of pronunciation teaching, one of the reasons for this failure is because of the curriculum itself.

Regarding the philosophical values of the 2004 curriculum, the adoption of the communicative approach also ends with some complicated problems, especially related to the main objective of language teaching and learning. In Indonesia, the main objective of English language education is to promote discourse competence (i.e., students' communicative ability, both in oral and written language in any communicative events). In order to effectuate the goal, learners also have to learn other competences: actional competence, linguistic competence, socio-linguistic competence, and strategic competence. Thus, discourse competence is the final goal of language learning while the other competences are treated as the supportive competences but should be firstly acquired (Depdiknas, 2004). However, practically the treatment of the four competences is not equal. A great attention is only directed to the actional competence which is promptly realised into four language skills whereas the other competences are not sufficiently elaborated. In the case of linguistic competence, for example, the curriculum just provides its outline - phonology is just divided into segmental and suprasegmental features - without any further explanation what to teach and how to deal with these features. This narrow understanding of communicative ability and lack of real guidelines will result in ignorance of language components, particularly pronunciation which is one of the essential keys for retaining Indonesian EFL learners' intelligibility in oral communication.

Despite uncertain guideline of pronunciation teaching, the schoolbased educational system has been implemented in Indonesia so that teachers of English at school level are able to develop their own teaching material based on the designated core curriculum. English teachers also have an opportunity of articulating their own beliefs and assumptions because they are the only ones who know what happens in their classrooms. Teachers are definitely positioned not only as the doers of denominated curriculum but also as decision makers of what they are 
doing in language classrooms. This makes a balance of a technology of language teaching and an ecological perspective on language teaching as described by Tudor (2001).

Regarding the expectation of English as an international language and the real condition of what happens to English education in Indonesia, I decided to conduct a study on Indonesian EFL teachers' perceptions of the priorities in pronunciation teaching for Indonesian EFL learners. The following three research questions were formulated:

(1) What English variety is appropriate for Indonesian EFL learners?

(2) What components of pronunciation are important for Indonesian EFL learners?

(3) What techniques for teaching pronunciation are appropriate for Indonesian EFL learners?

\section{METHOD}

\section{Participants}

A total of 37 Indonesian EFL teachers ( 25 males and 12 females) of public junior high schools in Lombok Timur, the province of Nusa Tenggara Barat, Indonesia, voluntarily participated in the study by using opportunistic random sampling. The participants were randomly chosen from all of the public junior high schools with considerations of taking advantage of the unexpected flexibility such as the participants' interest in the topic of the study, education background, and teaching experience. These participants had different levels of English language education backgrounds: 11 teachers had Diploma in Education of English Language Education and 26 teachers had Bachelor of Education in English Language Education. These teachers had teaching experience of various length: 4 teachers with 1-5 years of teaching experience; 11 teachers with 6-10 years of teaching experience; 14 teachers with 11-15 years of teaching experience; and 8 teachers with more than 15 years of teaching experience.

\section{Data Collection}

The data of the study was primarily collected by means of a paperform questionnaire. The questionnaire included three aspects of pronunciation: (1) the English varieties (Q1) comprising American English, 
Australian English, British English, international English, and Indonesian English; (2) the components of pronunciation (Q2) consisting of accurate consonants, accurate vowels, prominence (sentence stress), rhythm patterns, intonation patterns, and word stress; and (3) the techniques for teaching pronunciation (Q3) being composed of teacher explanation in L1, sound discrimination, tongue twister, listen-and-repeat, teacher demonstration, communicative practice, and drama and role play. The respondents were required to determine their own perceptions through a five-point Likert scale. The options of each question were coded from 1 (not appropriate for Q1; not important for Q2; not effective for Q3) to 5 (very appropriate for Q1; very important for Q2; and very effective for Q3). The questionnaire was designed to be anonymous and unregistered so that the respondents could honestly share their opinion.

To collect data, the master copy of the questionnaire was sent to the coordinator of this study in Indonesia who helped to collect data. The master copy of the questionnaire was reprinted and distributed directly (in person, not by mail) to the respondents of the study. After three weeks, the distributed questionnaire sheets were collected, packed, and sent back to the present researcher. The questionnaire sheets were sorted and only the data of the valid questionnaire sheets were tabulated and analysed.

In addition to the questionnaire, in-depth interview with four teachers was conducted to explore their views and practices in English pronunciation teaching in Indonesian EFL classrooms, focusing on the perceptions of the preferable English varieties for Indonesian EFL learners, the components of pronunciation, and the techniques for pronunciation teaching. These four teachers were randomly identified on the basis of their teaching experience as indicated in the section of Participants. The interview took about $25-30$ minutes for each participant.

\section{Data Analysis}

The tabulated scores of the English varieties, the components of pronunciation, and the techniques for teaching pronunciation were averaged for each item of each question. In order to dichotomize each item of each question (into an appropriate/inappropriate group for Q1, an important/unimportant group for Q2, and an effective/ineffective group for Q3), the calculated mean scores were compared with the median (i.e., 3.00). 
In order to show the significance level of the difference among the mean scores, the data were also submitted to analytic statistics. Since Kolmogorov-Smirnov tests disclosed that the data of each item was not normally distributed and Levene's tests revealed that the variances in the questions were not equal, the data was submitted to Friedman tests to determine whether there was a significant difference in the mean ranks of the items for each question. Whenever the Friedman tests determined the difference in the mean ranks of the items, the data was then submitted to Wilcoxon signed-rank tests with different significant levels of Bonferroni correction (the level of significant [normally .05] was divided by the number of micro questions) to examine which pairs of the means of the micro questions were statistically significant different.

\section{FINDINGS AND DISCUSSION}

\section{English Varieties}

Table 1 presents the mean scores of the investigated English varieties and difference in respondents' perceptions of appropriateness. Comparing the mean scores of each English variety with the median, the study showed that while Indonesian English was considered as an inappropriate model of English pronunciation, international English was rated as the most appropriate English variety for Indonesian EFL learners, followed by American English, British English, and Australian English. A Friedman test discovered that there was a significant difference in the mean ranks of the investigated English varieties, $\chi^{2}(4, \mathrm{~N}=37)=83.64, p<.01$. Wilcoxon signed-rank tests revealed that there was a significant difference in the means of all the pairs of the English varieties, except for the pair of American English versus British English, as seen in Table 1. This implies that international English is more preferable than other English varieties by Indonesian EFL teachers.

The quantitative analysis is consistently justified by all the interview teachers' comments indicating that the new target of spoken English for Indonesian EFL learners should be international English. They assumed that not only would oral communication in English between native - nonnative speakers of English increase in the future, but also oral interaction among non-native speakers. For this reason, two of the interviewees who had more than ten years of teaching experience, needed a clear guideline of 
international communicative competence, especially related to pronunciation teaching.

Table 1. Mean Scores and Difference in Respondents' Perceptions of Appropriateness of English Varieties

\begin{tabular}{lcccccc}
\hline English Varieties & Mean & Rank & AusE & BrE & IndE & IntE \\
\hline American English & 3.92 & 2 & $0.60^{* *}$ & 0.03 & $1.89^{* *}$ & $0.51^{*}$ \\
Australian English & 3.32 & 4 & & $0.57^{* *}$ & $1.29^{* *}$ & $1.11^{* *}$ \\
British English & 3.89 & 3 & & & $1.86^{* *}$ & $0.54^{* *}$ \\
Indonesian English & 2.03 & 5 & & & & $2.40^{* *}$ \\
International English & 4.43 & 1 & & & & \\
\hline
\end{tabular}

Note. AusE = Australian English; BrE = British English; IndE = Indonesian English; IntE = International English. $* p<.05 ; * * p<.01$

The junior teacher, whose teaching experience was less than five years, insisted on exposing students to several models of English pronunciation, not only American or British English. This finding is consonant with the idea of EIL proposed by some applied linguists (e.g., Jenkins, 2000; McKay, 2002; Walker, 2001). Conversely, Indonesian English was rated as the least appropriate model for Indonesian EFL learners with native Englishes (i.e., American English, British English, and Australian English) coming between international English and Indonesian English. Compared with other Asian countries, for example, this finding is a sharp contrast to the situation in Japan where Japanese English is the second most preferred model for Japanese EFL learners (Jenkins, 2000). One most probable reason for the lowest rating of Indonesian English is the fact that the Indonesian language is not Indonesian EFL learners' mother tongue, but their second language. This situation, of course, is different from that in Japan, where the Japanese language is the first language for the Japanese learners of English. Thus, it is inevitable that learners' native language will interfere with the learning of English pronunciation; therefore, it is not possible or advisable to eradicate Japanese influence. This is reflected in their choice of the appropriate models of English pronunciation. 


\section{Components of Pronunciation}

Concerning the components of pronunciation, as shown in Table 2, the participants valued the segmental features (vowels and consonants) more positively than the suprasegmental ones (prominence, rhythm, intonation, and word stress). The segmental features were equally rated as the most important components of pronunciation. Among the suprasegmental features, the rating of prominence was the highest, followed by intonation and word stress, while that of rhythm was the lowest. As far as the mean scores and median comparison are concerned, the finding showed that all the investigated components of pronunciation were important for Indonesian EFL learners to study. A Friedman test discovered that there was a significant difference in the mean ranks of the components of pronunciation, $\chi^{2}(5, \mathrm{~N}=37)=40.82, p<.01$. As shown in Table 2, Wilcoxon signed-rank tests indicated that there was no significant difference in the means of the pairs of consonants and vowels. Likewise, there was no significant difference in the means of the pairs of intrasuprasegmental features, except for the pair of prominence versus rhythm. Performing a pair wise comparison test of each segmental feature versus each suprasegmental feature, the result showed that there was a significant difference in the means of all the pairs, with the exception of the pair of consonants versus prominence and that of vowels versus prominence.

Table 2. Mean Scores and Difference in Respondents' Perceptions of Importance of Components of Pronunciation

\begin{tabular}{lccccccc}
\hline Components & Mean & Rank & V & P & R & I & W \\
\hline Consonants & 4.46 & 2 & 0.03 & 0.19 & $0.60^{* *}$ & $0.38^{* *}$ & $0.41^{* *}$ \\
Vowels & 4.49 & 1 & & 0.22 & $0.63^{* *}$ & $0.41^{* *}$ & $0.44^{* *}$ \\
Prominence & 4.27 & 3 & & & $0.41^{* *}$ & 0.19 & 0.22 \\
Rhythm & 3.86 & 6 & & & & 0.22 & 0.19 \\
Intonation & 4.08 & 5 & & & & & 0.03 \\
Word Stress & 4.05 & 4 & & & & & \\
\hline
\end{tabular}

Note. $\mathrm{V}=$ vowels $\mathrm{P}=$ prominence; $\mathrm{R}=$ rhythm; $\mathrm{I}=$ intonation; $\mathrm{W}=$ word stress.

$$
* * p<.01
$$

The main issue of components of pronunciation which emerged from the interviews was a necessity of the balance treatment of both segmental and suprsegmental features in pronunciation teaching. All the teachers 
agreed that segmental and suprasegmental features should be the priority in pronunciation teaching. However, when the interviewees were asked a further question Which segmental and suprasegmental features should be considered more in pronunciation teaching?, all of them preferred segmental features (vowels and consonants) as their priority because they found that there was a significant difference between the system of English pronunciation and that of learners' mother tongue (the Sasak language of Lombok Island, Indonesia). This implies that Indonesian EFL teachers are still more concerned with the segmental features (consonants and vowels) than with the suprasegmental ones.

This finding notably contrasts with the present trend of pronunciation instruction for ESL/EFL learners. Numerous applied linguists (e.g. Bowen, Madsen, \& Hilferty, 1985; Florez, 1998; Wong, 1987) propose the suprasegmental features as the priority of pronunciation instruction rather than the segmental features. Bowen, Madsen, \& Hilferty (1985) claim that the priority order of pronunciation teaching should be fluency, stress, rhythm and intonation, and vowels and consonants. Florez (1998) argues that the suprasegmental features are more prominent in pronunciation instruction. Wong (1987) also supports the idea that the most relevant components of pronunciation which play a greater role in English communication are rhythm and intonation. In Indonesia context, this finding is closely related to the remarkable reasons for learners' difficulty in English pronunciation: (1) the absence of English sounds in learners' native language and (2) the different distribution of the same or similar sounds in the phonetic structure of English and that of their L1 (Moedjito, 2006). Thus, the absence of English sounds and the different distribution of the same or similar sounds in L1 and L2 prompt Indonesian EFL teachers to consider consonants and vowels as the priority of pronunciation instruction in Indonesian classrooms.

However, referring to the mean scores which were all greater than the median, the present study is consonant with some studies on the importance of the balance of the segmental and suprasegmental features (e.g., Jenkins, 2000; Ufomata, 1996). Jenkins (2000) proposes Lingua Franca Core (LFC) that requires the balance between the segmental features (consonants, consonant clusters, and vowels) and the suprasegmental features (particularly, nuclear stress or prominence). Moreover, Ufomata (1996) claims that vowels and consonants are the essential features of pronunciation along with sounds in combination, stress, and 
intonation. Taking these figures into consideration, we conclude that Indonesian EFL teachers qualitatively have the same view of the inclusion of both segmentals and suprasegmentals of English pronunciation although they quantitatively have different opinion of these features.

\section{Techniques for Teaching Pronunciation}

In terms of the techniques for teaching pronunciation, the participants rated sound discrimination as the most appropriate technique for teaching pronunciation, followed by listen-and-repeat, tongue twister, communicative practice, teacher demonstration, teacher explanation, and drama and role play, as indicated in Table 3.

Concerning the comparison between the mean scores and the median, the findings discovered that all the investigated techniques for teaching pronunciation were appropriate for Indonesian EFL learners. A Friedman test revealed that there was a significant difference in the mean ranks of the techniques for teaching pronunciation, $\chi^{2}(6, \mathrm{~N}=37)=42.51, p<.01$. Wilcoxon signed-rank tests disclosed that there was a significant difference in the means of the pairs of (1) teacher explanation versus sound discrimination and teacher explanation versus listen-and-repeat, and (2) drama and role play versus all the investigated techniques with the exception of teacher explanation and teacher demonstration. The finding is consonant with the proposal of utilising a variety of techniques for teaching pronunciation proposed by some applied linguists (e.g., Celce-Murcia et al., 1996; Dalton \& Seidlhofer, 1994). However, a careful analysis of teachers' perceptions of the investigated techniques for teaching English pronunciation indicates that the dominant technique is sound discrimination that typically makes use of minimal pairs.

These statistic findings are also supported by the interview participants' comments indicating that sound discrimination should be one of the essential techniques for teaching pronunciation (c.f. Annual Review of English Language Education in Japan, 2006). In addition to sound discrimination, teacher explanation in Indonesian language and teacher demonstration might be helpful for Indonesian EFL learners. However, these interview teachers surmised that teachers' knowledge of pronunciation might be still a major problem. They presumed that many teachers did not have sufficient knowledge of pronunciation. Even one teacher said that she felt uncomfortable to teach pronunciation because of her limited 
knowledge of pronunciation. These views indicate that Indonesian EFL teachers need professional development which provides them with knowledge of pronunciation as well as skills of how to teach pronunciation and of how integrate pronunciation in language classrooms.

Table 3. Mean Scores and Difference in Respondents' Perceptions of Effectiveness of Techniques for Teaching Pronunciation

\begin{tabular}{ccccccccc}
\hline Techniques & Mean & Rank & SD & TT & LR & TD & CP & DR \\
\hline TE & 3.89 & 6 & $0.60^{* *}$ & $0.46^{* *}$ & $0.57^{* *}$ & 0.27 & $0.38^{* *}$ & 0.13 \\
SD & 4.49 & 1 & & 0.14 & 0.03 & $0.33^{*}$ & $0.22^{*}$ & $0.73^{* *}$ \\
TT & 4.35 & 3 & & & 0.11 & 0.19 & 0.08 & $0.59^{* *}$ \\
LR & 4.46 & 2 & & & & $0.30^{*}$ & 0.19 & $0.70^{* *}$ \\
TD & 4.16 & 5 & & & & & 0.11 & $0.40^{* *}$ \\
CP & 4.27 & 4 & & & & & & $0.51^{* *}$ \\
DR & 3.76 & 7 & & & & & & \\
\hline
\end{tabular}

Note. $\mathrm{TE}=$ teacher explanation in $\mathrm{L} 1 ; \mathrm{SD}=$ sound discrimination; $\mathrm{TT}=$ tongue twister; $\mathrm{LR}=$ listen and repeat; $\mathrm{TD}=$ teacher demonstration; $\mathrm{CP}=$ control practice; $\mathrm{DR}=$ drama and role play. $* p<.05 ; * * p<.01$

\section{CONCLUSION AND SUGGESTION}

The present study investigated Indonesian teachers' perceptions of the priorities in the teaching of pronunciation for Indonesian EFL learners focusing on the English varieties, the components of pronunciation, and the appropriate techniques for teaching pronunciation. Although the study has revealed some interesting findings, it has its limitations such as the sample of the study. The number of the teachers who were involved in the study, especially those who were interviewed, is relatively small. It is not possible to ascertain how wide-spread these findings are among other teachers. Nevertheless, considering international English is the most appropriate variety for Indonesian learners, the study suggests that learners should be exposed to a more balance treatment of the segmental and suprasegmental features by using a variety of techniques. However, the fact that practically teachers do not really know the features of English phonological and phonetic structures determining intelligible pronunciation still becomes one 
of the remaining issues. Therefore, further research should be conducted to investigate which features of English are important for Indonesian EFL learners and which of these features they should pay more attention to.

\section{REFERENCES}

Annual Review of English Language Education in Japan (ARELE). (2006). Priorities in the teaching of pronunciation for Indonesian EFL learners. Proceedings of the 32nd National Conference of the Japan Society of English Language Education. Kochi: Kochi University.

Basir, N. L. (2002). Bahasa Inggris: Sulit dipelajari atau sulit diajarkan? [English: Is it difficult to learn or to teach?]. Pendidikan Network [Education Network]. Retrieved September 19, 2005, from http://artikel.us/laely-basir.html

Bowen, J. D., Madsen, H., \& Hilferty, A. (1985). TESOL techniques and procedures. Massachusetts: Newbury House Publishers.

Celce-Murcia, M., Brinton, D. M., \& Goodwin, J. M. (1996). Teaching pronunciation: A reference for teachers of English to speakers of other languages. Cambridge: Cambridge University Press.

Cruttenden, A. (2001). Gimson's pronunciation of English (6th ed.). London: Arnold Publisher.

Dalton, C., \& Seidlhofer, B. (1994). Pronunciation. Oxford: Oxford University Press.

Depdiknas. (2004). Kurikulum dan hasil belajar mata pelajaran bahasa Inggris sekolah lanjutan tingkat pertama [English curriculum and achievement for junior high school]. Jakarta: Pusat Kurikulum Balitbang Depdiknas RI.

Florez, M. C. (1998). Improving adult ESL learners' pronunciation skills. Digests. Retrieved March 3, 2004, from http://www.cal.org/caela/esl_resources/ digests/Pronun.html

Jenkins, J. (2000). The phonology of English as an international language. Oxford: Oxford University Press.

Jenner, B. (1989). Teaching pronunciation: The common core. Speak Out! 4, 2-4.

McKay, S. L. (2002). Teaching English as an international language. Oxford: Oxford University Press.

Moedjito. (2006). A study on perceptions of pronunciation among Indonesian EFL teachers and students. Unpublished master's thesis, Naruto University of Education, Naruto, Tokushima. 
Soenjono, D. (2001). Mengapa pengajaran bahasa kita gagal? [Why is our language teaching unsuccessful?]. Intisari. Retrieved September 19, 2005, from http://www.indomedia.com/ intisari/2001/Nov/warnasoenjono1.htm

Sudiyana, M. (2005). Tamat SMU mampu berkomunikasi bahasa Inggris: Siapkah pak guru? [Having English communicative ability after senior high school: Are the English teachers ready?]. Banjarmasin Post. Retrieved September 19, 2005, from http://www.indomedia.com/bpost/072005/19/opini/ opinil. htm

Tudor, I. (2001). The dynamics of the language classroom. Cambridge: Cambridge University Press.

Ufomata, T. (1996). Setting priorities in teaching English pronunciation in ESL contexts. Phonetics and Linguistics. Retrieved May 2, 2004, from http://www.phon.ucl.ac.uk/home/ shl9/ufomata/titi.htm

Walker, R. (2001). Pronunciation for international intelligibility. English Teaching Professional, 21. Retrieved December 11, 2005, from http://www3.telus. net/linguisticsissues/internationalintelligibility.html

Wong, R. (1987). Teaching pronunciation: Focus on English rhythm and intonation. Englewood Cliffs, NJ: Prentice-Hall Regents. 